\title{
The role of family and social media in athlete social interactions
}

\author{
Aulia Gusdernawati* ${ }^{(1)}$, Widiyanto \\ Universitas Negeri Yogyakarta, Indonesia
}

Received: 30 January 2021; Accepted 21 March 2021; Published 20 July 2021 Ed 2021; 6(2): 130-139

\begin{abstract}
Social interaction is an inseparable part of human life, including an athlete, because literally, humans are social creatures. Social interactions carried out in society can be influenced by other factors such as family and social media. This study aims to determine how many roles out social media both on the social interaction of athletes. This research is quantitative research with the instrument used is a questionnaire. The population in this study was 70 National athletes from Riau Province. The analysis technique used is descriptive quantitative in the form of a percentage. The results revealed that the family has a good role with a value of $32.86 \%$, while social media does not have enough roles with a percentage obtained of $40 \%$ and for both family and social media have a sufficient role of $34.29 \%$. Social media and family have an adequate role for athletes in social interaction. This study has several limitations including the limited area and scope of research subjects.
\end{abstract}

Keywords: Athletes; social media; family; social

https://doi.org/10.25299/sportarea.2021.vol6(2).6347

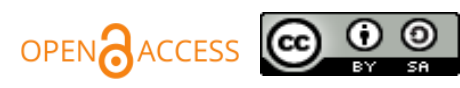

Copyright (C) 2021 Aulia Gusdernawati,Widiyanto

Corresponding author: Aulia Gusdernawati, Postgraduate Program of Sport Science, Universitas Negeri Yogyakarta, Yogyakarta, Indonesia

Email: auliagusdernawati.2020@student.uny.ac.id

How to Cite: Gusdernawati, A., \& Widiyanto. (2021). The role of family and social media in athlete social interactions. Journal Sport Area, 6(2), 130-139. https://doi.org/10.25299/sportarea.2021.vol6(2).6347

\section{INTRODUCTION}

Humans as social beings have the meaning that there are interactions that occur between humans and other humans, and with the environment. Inah (2013) revealed that humans are social creatures who live in groups and need each other. Social interactions and activities are habits that occur in social life, it is further explained that interaction is a relationship between individuals and individuals, individuals with groups, and groups with groups based on human characters who need one another (Pranata, 2017). As social beings and living in groups in everyday life, of course, the name of the interactions therein cannot be missed. Syaputra (2020) humans are social creatures in which social interaction and communication occur. Social communication and social interaction in society carried out by individuals can form character. The character formed in this individual is influenced by several other factors.

Continuing to explain the supporting factors for character formation that have a relationship with social interaction, sport is one of them as a means of shaping personality as well as characteristics of athletes when interacting socially (Inah, 2013). Sitepu (2017) revealed that sports can form positive characters that affect a person's personality and social activities with their environment. Talking about sports, someone who is engaged in and has a special interest in certain sports is called an athlete. In line with this statement, Setiyawan (2017) explains that the definition of an athlete is someone who is involved in the world of sports 
and becomes an expert in the sport he is involved in. Apart from exercising, social interaction and social communication are influenced by other factors, namely family.

Talking about family will affect an individual personality. If observed properly, the personality that becomes this character is related to social interaction and social communication. In line with this statement, research by Yunistiati et al., (2014) reveals that there is a significant relationship that shows positive things between family harmony and individual personality on their social interactions. Kurniawati (2017) the behavior of athletes affects how their family supports them. Gunawan et al., (2015) revealed that parental support has a positive effect on personality on one's social activities and sports. Framanta (2020) states that the family is the first and foremost educational institution, which will determine the future of an individual's life.

Apart from sports and family, there is one factor that influences other social interactions, namely social media. Social media is one of the factors that influence individual social interactions today, this is due to current technological advances. Melis (2016) explains that the development of information technology, the use of the internet in the field of education, continues to develop and affects how people socialize. Aiyuda and Syakarofath (2019) social media is more on individual internal factors such as personality related to how humans in society tend to be more active on social media compared to direct social interactions.

The social interactions possessed by athletes will affect how achievement and success in sports. In line with this, Ratimiasih (2018) explained that the social interaction possessed by athletes is an important component in establishing cooperation between members to gain knowledge about mutual openness and mutual respect, positive competition in each athlete can make better achievements. Sinulingga et al., (2020) revealed that athletes' achievements can be influenced by social agents including family support, social media, peers, and social interactions that occur in the field. Furthermore, it was explained that the higher the social agent or social interaction possessed by the athlete, the greater the influence it will have on athletes' achievement in sports in the PPLP athletes environment of North Sumatra Province. Rumahpasal et al., (2020) revealed that the social interactions that athletes have will affect how successful they are in sports, especially for team sports.

Although it is explained that social interaction is an important component of athlete performance support a literature review reveals that currently, athletes' social interactions are not good. In line with this opinion, the results of research by DeFreese and Smith (2014) explained that the lack of social interaction carried out by athletes recently will affect how emotions occur before sports competitions. The athlete's social interaction is less likely to result in the athlete's lack of psychological health to be competitive. Irwanto and Romas (2019) revealed that the social interactions that exist in the athlete's environment are not wellestablished, so there is a lack of communication in carrying out competition competitions. Akurat and Maksum (2021) reveals that currently, low social interaction occurs between individuals who carry out sports activities. Furthermore, low social interaction affects the mood in doing sports and affects the presence they have. Nixdorf et al., (2020) explained that several factors that influence the achievement of not optimal sports activities are influenced by the lack of social interaction that occurs in the athlete's environment.

Based on the existing problems regarding the low social interaction possessed by athletes. Researchers will research how the role of family and social media for athletes who are individuals who do sports activities seen in their activities and social interactions and communication. The purpose of this study was to provide descriptions of how social media and family play a role in athletes' social behavior. This research is a renewal of research results because until now there has been no research result that reveals how the role of family and social media simultaneously towards athletes and their environment, especially athletes in Riau Province. The results of this study are expected to provide benefits, namely for the foundation of coaches or people who are involved in the world of sports to increase or give attention to things that will affect the social interaction of athletes so that they can provide maximum performance in sports. 


\section{METHODS}

This type of research is observational research with a quantitative descriptive design. The sample in this study amounted to 70 national athletes from Riau Province consisting of men and women. The sample selection technique is random sampling. The sample selection is done randomly, if the sample is more than 100 people taken $25-30 \%$, but in this study 70 athletes have not reached 100 so that all of them become the research sample. In this research, we will describe the role of social media and the role of the family in athletes' social activities. This measurement uses an instrument in the form of a social interaction questionnaire for athletes that have been validated by experts using a Likert scale in the form of five assessment categories, namely, very good, good, adequate, insufficient, very poor with a value of validity and reliability of 0.941 . The research was carried out by distributing questionnaires through a google form. The research was carried out from November 20 to December 5, 2020. In this study, there were 2 variables measured by standard research instruments. Data analysis. At the initial stage, a descriptive analysis was carried out using SPSS version 25 to determine the value of the role of family and social media on the behavior of athletes outside the field in society.

\section{RESULTS AND DISCUSSION}

\section{Descriptive Analysis Results}

The results of the descriptive analysis of data carried out regarding the role of social media and family towards social athletes in Riau Province, totaling 70 people who are National athletes who will compete in PON 2021 in Papua are presented in table 1 below:

Table 1. Descriptive Analysis Results

\begin{tabular}{|c|c|c|c|c|c|c|}
\hline \multicolumn{7}{|c|}{ Statement Criteria } \\
\hline No. & Indicators & SS & $\mathbf{S}$ & TS & STS & Score \\
\hline 1. & Social media and family & 710 & 630 & 434 & 326 & 512 \\
\hline 3. & Family & 312 & 247 & 180 & 171 & 271 \\
\hline 2. & Social media & 398 & 383 & 254 & 155 & 241 \\
\hline
\end{tabular}

Table 1 above presents data regarding the acquisition obtained from the questionnaire to determine the role of social media, family, and the role of both of them in social athletes. The results of the analysis on the social media and family role questionnaire totaling 512 include four answers from the statements given, namely, strongly agree with the total value of 710, agree with the value of 630, disagree with a value of 434 , and strongly disagree 326 totaled 271 , with a value of strongly agree 312 , agree 247 , disagree 180 , and strongly disagree 171 . The overall value obtained in the social media statement questionnaire totaled 241 with the acquisition of strongly agree 398, agree, 383, disagree 254, and strongly disagree 155 . To understand the value obtained and map out the categories for each variable role, namely family, social media, and both together, will be explained in detail for each indicator.

\section{a. Family Role}

Based on the results of the analysis of family role data obtained from 70 subjects, it shows that the results of descriptive analysis at the maximum value obtained are 52 , while the minimum value is 39 , the standard deviation obtained is 3.801. And the average value obtained is 45.89 . This explanation is presented in table 2 below to make it easier to read.

Table 2. Results of Descriptive Analysis of the Role of the Family

\begin{tabular}{lccccc}
\hline & N & Minimum & Maximum & Mean & Std. Deviation \\
\hline Family & 70 & 39 & 52 & 45.89 & 3.801 \\
Valid N (listwise) & 70 & & & & \\
\hline
\end{tabular}

After explaining the descriptive analysis results shown in table 1, the calculation is then carried out to categorize the achievements obtained in the role of the family on the social activities of athletes which 
greatly affect the athlete's achievement, the categories obtained in each analysis calculation can be seen in graph 1 below:

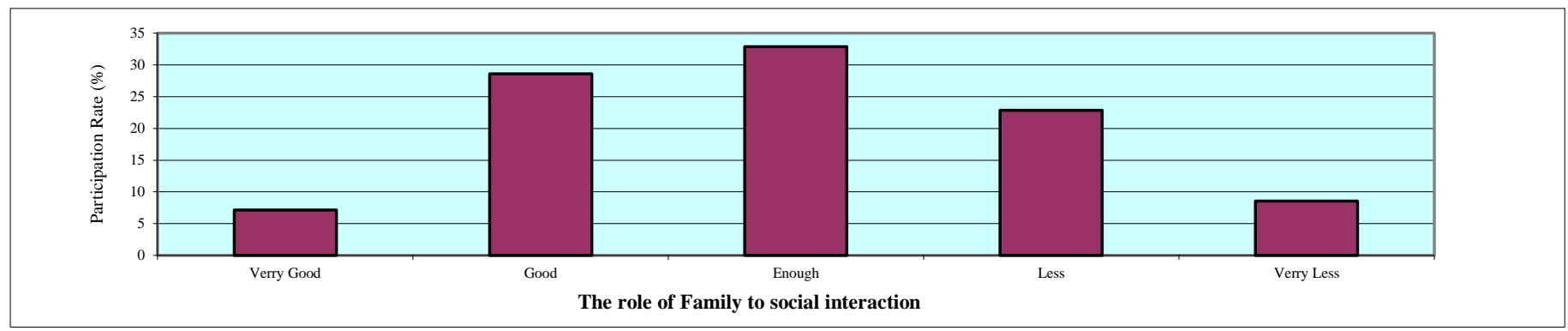

Graph 1. Bar Diagram of Family Categories Against Social Interaction

Based on the results presented in figure 1 above, it is known that there are four categories of assessment, namely very good, good, adequate, lacking, and very poor. From a total of 70 subjects, it was found that $7.14 \%$ were in the very good category, then $28.57 \%$ were in a good category, $32.86 \%$ were enough category, $22.86 \%$ were in the poor category, and $8.57 \%$ were very poor. The highest and most percentage value is in a sufficient category of $32.86 \%$. Based on the category table, it can be explained if the family has a role that is quite influential in how athletes carry out their social interactions.

\section{b. Social Media Role}

Based on the results of data analysis on the role of social media obtained from 70 subjects, it shows that the results of descriptive analysis at the maximum value obtained are 68 , while the minimum value is 51, the standard deviation obtained by the calculation results is 4.649. And the mean value obtained is 58.43. This explanation is presented in table 3 below to make it easier to read.

Table 3. Results of Descriptive Analysis of the Role of Social Media

\begin{tabular}{lccccc}
\hline & N & Minimum & Maximum & Mean & Std. Deviation \\
\hline Social Media & 70 & 51 & 68 & 58.43 & 4.649 \\
Valid N (listwise) & 70 & & & & \\
\hline
\end{tabular}

After explaining the descriptive analysis results shown in table 3 above, then the calculation is carried out to categorize the achievements obtained in the role of the family towards the athlete's financial activity which greatly affects the athlete's performance, the categories obtained in each analysis calculation can be seen in graph 2 below:

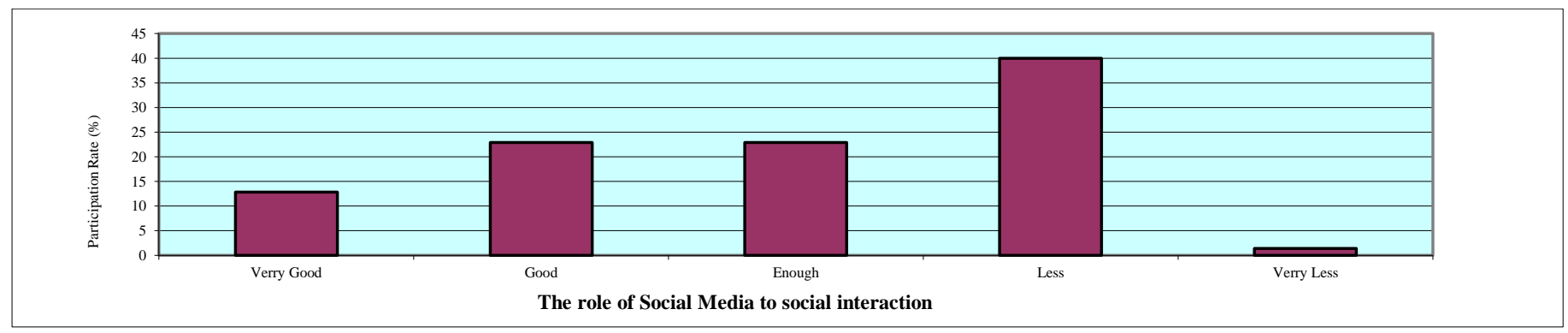

Graph 2. Bar Diagram of Social Media Categories of Social Interaction

Based on the results presented in table 4 above, it is known that there are four categories of assessment, namely very good, good, sufficient, lacking, and very poor. From a total of 70 subjects, it was found that $12.86 \%$ were in the very good category, then $22.86 \%$ were in a good category, $22.86 \%$ were in enough category, $40 \%$ were in the poor category and 1.47 were very poor. The highest and most percentage value is 
in less category, which is $40 \%$. Based on the category table, it can be explained that social media has less influence on how athletes carry out their social interactions.

\section{c. The Concurrent Role of Social Media and Family}

Based on the results of data analysis on the role of social media obtained from 70 subjects, it shows that the results of a descriptive analysis on the maximum results obtained are 120, while the minimum value is 91 , the standard deviation obtained by the calculation results is 7,788 . And the mean value obtained is 104.31. This explanation is presented in table 4 below to make it easier to read.

Table 4. Results of Descriptive Analysis of the Role of Family and Social Media

\begin{tabular}{lccccc}
\hline & N & Minimum & Maximum & Mean & Std. Deviation \\
\hline Family and Social Media & 70 & 91 & 120 & 104.31 & 7.788 \\
Valid N (listwise) & 70 & & & & \\
\hline
\end{tabular}

Based on table 1 above, statistical descriptive data is obtained, namely from 70 research subjects obtained 91 minimum values and 120 maximum values and standard deviation obtained 7,788 with the mean value obtained is 104.3. To understand the categories obtained regarding social media and family with social interaction, it can be seen in graph 3 below.

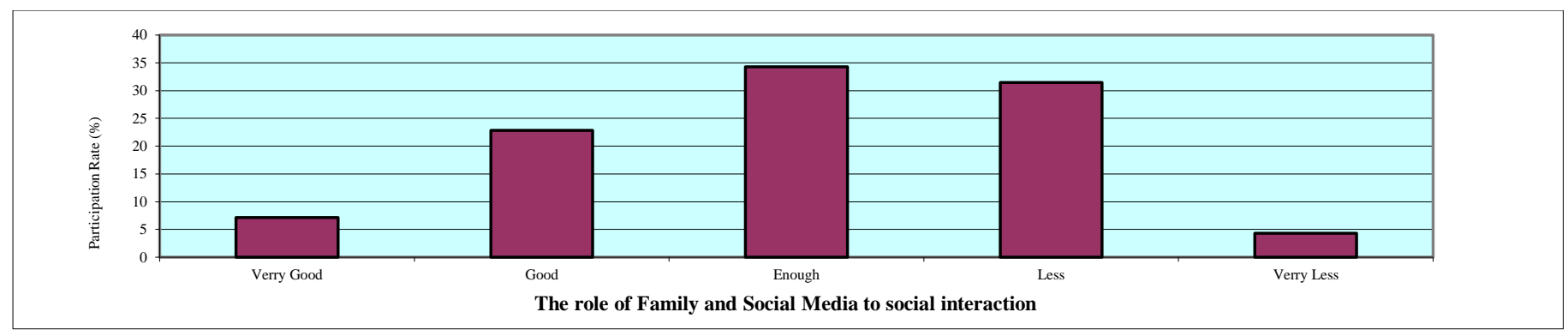

Graph 3. Bar Chart of Family and Social Media Categories of Social Interaction

Based on the results of the analysis, it was found that, of the total number of samples, there were 5 in the very good category with a gain of $7.14 \%$, then for the good category there were 16 subjects with a gain of $22.86 \%$, in the sufficient category, there were 24 subjects with a percentage value of $34.29 \%$. For the next category, there are less than 22 people with a percentage value of $31.43 \%$, the last is the very poor category, the percentage value is $4.28 \%$. Based on the percentage results obtained in the sufficient category is the largest percentage, namely, $34.29 \%$ so that it can be explained if social media and family have a sufficient relationship with the athlete's social interaction.

Based on the results of the analysis, it was found that the family has a sufficient role for athletes to carry out social interactions, this is indicated by the number of percentages obtained in sufficient categorization of $32.86 \%$. Previous studies discussing the role of the family towards the society of athletes are very limited but some explain the same thing as the research that has been done. This result is in line with research by $\mathrm{Al}$ Sudani and Budzyńska (2018) which revealed that family parenting plays an important role in the life of athletes in the future. Furthermore, it was revealed that life regarding how parental beliefs can affect the confidence of a young athlete and the quality of a good relationship between athletes and colleagues is reflected in how the family's role in athletes. Aparicio (2014) developed and explained Freud's theory because it deals with the psychological development of the family and social origins, as well as the dynamic and interactive roles that family and communities have after influencing individuals and their subsequent behavior habits. Rahayu et al., (2018) explained that through physical activity carried out by individuals, they can increase personal responsibility for their social interactions.

The support given by family to individuals affects the attitudes and characteristics of the individual at school. It is further stated that the focus on the role of the family in providing individual care has quite positive implications for productive family-school-community relationships (Stefanski et al., 2016). The 
way a child socializes in the environment is influenced by how much love is in the family. It is further disclosed, if a child in a family who has a magnitude of love is like creating a child who will warm to his social environment (Baferani, 2015). Family is an important component in social life both in social interaction in the community. It is further disclosed, if in the theory of family systems, it has a positive relationship to how an individual behaves in society both in interaction with external systems, such as sports, school, or church. Erida (2018) revealed that sports are activities that can be done by everyone. It will be further discussed if the sport is also a medium for interaction between one human and another.

Dalen and Seippel (2019) Good communication within an athlete's family will affect the athlete's performance in the field, besides this also affects how athletes communicate to other people such as coaches, sports friends, and even the community when the athlete is outside the training environment (Erdner \& Wright, 2018). Li et al., (2017) revealed that a child who has a good relationship in the family can communicate well at school, and can interact well with other environments besides school. Further disclosed, if the family is an important component in shaping the personality for social interactions in children. Procentese et al., (2019) explained that if the family is the initial foundation for learning in children, how children's attitudes to social interactions are influenced by parents about how a child will be able to manage himself in social interactions.

After explaining to the family about the athlete's social interaction, the results of the next analysis are about the role of social media on the athlete's social interaction. The results of the analysis showed that social media was in the less category by $40 \%$. The results of this analysis, if it is related to the existing literature review, are different, the results of several literature studies reveal that social media has a role in athletes' social interactions. As research conducted by Filo et al., (2015) explained that social media can affect athletes' social interactions, in addition to social media social interactions can lead to consumptive behavior in athletes. Furthermore, it is said to be consumptive because through social media athletes imitate how favorite athletes wear clothes which causes the desire to follow them. Through social media, athletes can interact well even though not directly. In China, the use of social media is considered very helpful for journalists in gathering information about athletes even though they do not meet directly. Furthermore, it was revealed that some athletes in the study admitted that social media had an impact on the growth of social interaction (Li et al., 2017).

McAdow et al., (2017) stated that university student-athletes and their teams rely on social media to communicate with their fans, and this interaction may be of benefit to teams and athletes. But the use of social media also carries a risk if a photo or statement goes viral. Burns (2018) explained that social media affects how athletes interact in college. Furthermore, it was revealed that the use of media properly can provide long-distance social interaction for athletes in college. Social media as a whole does not affect the interaction and social personality of athletes, but social media is currently experiencing developments to promote sports, brands of sports, and fashion (Pilar et al., 2019). Cranmer, Cassilo, Sanderson, and Troutman (2019) revealed that social media is one of the tools that can be used to interact between sports fans and athletes, it is further revealed that the use of media facilitates the interaction of athletes with fans who may come from outside the city and even abroad.

Mayuni, Gelgel, and Pascarani (2019) revealed the results of the study, namely, showing that the use of social media had a significant positive effect on face-to-face social interaction at the Sekaa Teruna, Desa Adat Kuta, Badung, Bali. These results indicate that the higher the use of social media, the higher the faceto-face social interaction in the Traditional Village of Sekaa Teruna Kuta, Badung, Bali. Social media owned by athletes can influence how the social nature and social skills of sports (for example, individuals experience, group cohesion, or general social beliefs) and its consequences (eg enjoyment, inclusion, or social capital) depending on social networks in sports teams (Dalen' \& Seippel, 2019). The emergence of social media as technological advancement completely changes the way athletes interact, even with the existence of social media increasing the willingness of individuals to do sports due to seeing role models in social media. Further explained by using social media athletes who may not have met in person can communicate as if they have known them for a long time (Stefanski et al., 2016). 
Whereas for the results of the analysis carried out the roles of both, namely family and social media, get a sufficient role with the value obtained is $34.29 \%$. When viewed from the acquisition of each one who has a more role is the family towards the athlete's social interaction. The results of this study, if associated with previous literature studies, are very limited in the discussion of athletes, however, there are several research results that reveal that both are important components in the story of how a person interacts with their social life. The results of research by Xin and Fitriana (2020) explained that the interactions carried out by athletes both inside and outside the field are influenced by family factors, but the development of times also mentions that apart from family, the things that affect how the interaction of athletes with coaches, fellow sportsmen or others is through social media. Further disclosed if both will also affect the performance of athletes in the field. Viandari and Susilawati (2019) revealed that the role of family and social medicine must be properly considered and considered so that they can go hand in hand because both have a large enough role in how to form a child in interacting with the environment and society. Furthermore, it was revealed that both are important components in making a child's reflection in the applied parenting style.

Aparicio (2014) revealed that if family and social medicine can affect individuals positively and negatively if not done correctly then in social life the interaction that someone displays are a story taught by the family but not only the family can also be influenced by the social media they have. It is further disclosed if the two have a relationship in how a person interacts with his social environment. Procentese, López-Carril et al., (2020) explained that a child who gets support from family and good social media assistance can actively engage in social interactions in the community. It was further explained that the child would be more confident in communicating openly in the community. Harman et al., (2019) social interactions and interpersonal relationships between individuals are affected by several things, including family, besides family, seeing the development of a very advanced era. This can be seen how an athlete who is active and not in the use of social media when in the community.

\section{CONCLUSION}

Based on the results of the analysis obtained, it shows that the role of family and social media simultaneously is quite the role of an athlete in social interaction in their environment, this is reflected in the acquisition of presentations in the category which states that these two factors play a role in athlete interaction. This means that how the athlete's life in social interactions in society is also reflected in how the family is and how active it is in the use of social media. This research is a research renewal because until now there have been no results that reveal how the role of family and social media are in the social interactions of athletes in society, especially in the National athletes of Riau Province. There are several limitations in this study, namely the number of samples and the areas covered by the research. For further research, it is hoped that it will be able to reach a wider sample and area regarding the role of family and social media on the social interaction of athletes, maybe other variables that include athletes' achievements in future research can be added.

\section{REFERENCES}

Aiyuda, N., \& Syakarofath, N. A. (2019). Presentasi diri di sosial media (Instagram dan Facebook) Sebuah literature review. PSYCHOPOLYTAN (Jurnal Psikologi), 2(2), 124-130.

Akurat, Y., \& Maksum, A. (2021). Faktor-faktor penyebab rendahnya partisipasi siswa putri dalam ekstrakurikuler futsal di SMAN 18 Surabaya. JPOK, 9(1), 71-77.

Al Sudani, A. A. D., \& Budzyńska, K. (2018). Family and its Influence on how Athletes Function. LASE Journal of Sport Science, 5(2), 115-119. https://doi.org/10.1515/ljss-2016-0037

Aparicio, A. R. (2014). Family and Social Dynamics. Athene Noctua: Undergraduate Philosophy Journal, $2(2), 1-4$. 
Baferani, M. H. (2015). The Role of the Family in the Socialization of Children. Mediterranean Journal of Social Sciences, 6(6), 417-423. https://doi.org/10.5901/mjss.2015.v6n6s6p417

Bergesen-Dalen, H., \& Seippel, Ø. (2019). Social networks and gender in organized youth sports. European Journal for Sport and Society, 16(4), 323-341. https://doi.org/10.1080/16138171.2019.1693143

Cranmer, G. A., Cassilo, D., Sanderson, J., \& Troutman, B. (2019). Social Media Discourse About DivisionI Football Players' Early Exit Announcements: The Role of Expressed Fandom. Communication and Sport, 9(4), 1-26. https://doi.org/10.1177/2167479519874804

Dalen', H. B., \& Seippel, Ø. (2019). Social networks and gender in organized youth sports. European Journal for Sport and Society, 16(4), 323-341. https://doi.org/10.1080/16138171.2019.1693143

DeFreese, J. D., \& Smith, A. L. (2014). Athlete social support, negative social interactions, and psychological health across a competitive sport season. Journal of Sport and Exercise Psychology, 36(6), 619-630. https://doi.org/10.1123/jsep.2014-0040

Erdner, S. M., \& Wright, C. N. (2018). The Relationship Between Family Communication Patterns and the Self-Efficacy of Student-Athletes. Communication and Sport, 6(3), 368-389. https://doi.org/10.1177/2167479517711450

Erida, M. (2018). The Impact of Sport Activities on the Decrease of PLWHA Stigma and Social Values Megia. Jurnal Pendidikan Jasmani dan Olahraga, 3(1), 122-128. https://doi.org/10.17509/jpjo.v4i2.18038

Filo, K., Lock, D., \& Karg, A. (2015). Sport and social media research: A review. Sport Management Review, 18(2), 166-181. https://doi.org/10.1016/j.smr.2014.11.001

Framanta, G. (2020). Pengaruh Lingkungan Keluarga Terhadap Kepribadian Anak. JPdK, 1(2), 62-63. https://doi.org/10.31004/jpdk.v1i2.654

Gunawan, A. R., Rusyidi, B., \& Meilany, L. (2015). Dukungan Sosial Orangtua Tehadap Atlet Paralimpik Pelajar Tuna Netra Berprestasi di Kota Bandung. Prosiding Penelitian dan Pengabdian Kepada Masyarakat, 3(3), 407. https://doi.org/10.24198/jppm.v3i3.13785

Harman, B., Kosirnik, C., \& Philippe, R. A. (2019). From social interactions to interpersonal relationships: Influences on ultra-runners' race experience. PLoS ONE, 14(12), 1-21. https://doi.org/10.1371/journal.pone.0225195

Inah, E. N. (2013). Peranan komunikasi dalam pendidikan. Jurnal Al-Ta'dib, 6(1), 176-188.

Irwanto, \& Romas, M. Z. (2019). Profil Peran Psikologi Olahraga Dalam Meningkatkan Prestasi Atlet di Serang-Banten Menuju Jawara. In Prosiding Seminar Nasional IPTEK Olahraga (SENALOG) (Vol. 2, No. 1).

Kurniawati, A. (2017). Perilaku Sosial Atlet Puteri Cabang Olahraga Futsal. Jurnal Komunikasi Universitas Garut: Hasil Pemikiran dan Penelitian, 3(2), 21-30. http://dx.doi.org/10.10358/jk.v3i2.570 
Li, B., Stokowski, S., Dittmore, S. W., \& Scott, O. K. M. (2017). For better or for worse: The impact of social media on Chinese sports journalists. Communication and Sport, 5(3), 311-330. https://doi.org/10.1177/2167479515617279

López-Carril, S., Escamilla-Fajardo, P., González-Serrano, M. H., Ratten, V., \& González-García, R. J. (2020). The Rise of Social Media in Sport: A Bibliometric Analysis. International Journal of Innovation and Technology Management. 17(6), 1-30. https://doi.org/10.1142/S0219877020500418

Mayuni, I. G. A. A. R., Gelgel, N. M. R. A., \& Pascarani, N. N. D. (2009). Pengaruh Penggunaan Media Sosial Terhadap Interaksi Sosial Pada Sekaa Teruna Desa Adat Kuta, Badung, Bali. Jurnal Ilmu Sosial, $4(2), 1-6$.

McAdow, B., Jung, J.-H., Lambiase, J., \& Bright, L. (2017). Penalties Off the Field: Exploring Social Media Policies for Student Athletes at Universities. The Journal of Social Media in Society, 6(2), 368-405.

Melis. (2016). Pengaruh Media Sosial Terhadap Kepribadian Mahasiswa. Mizan: Journal of Islamic Law, 4(2), 327-336. https://doi.org/10.32507/mizan.v4i2.186

Nixdorf, I., Beckmann, J., \& Nixdorf, R. (2020). Psychological Predictors for Depression and Burnout Among German Junior Elite Athletes. Frontiers in Psychology, 11(April), 1-13. https://doi.org/10.3389/fpsyg.2020.00601

Pilar, P. M., Rafael, M. C., Félix, Z. O., \& Gabriel, G. V. (2019). Impact of sports mass media on the behavior and health of society. A systematic review. International Journal of Environmental Research and Public Health, 16(3), 1-12. https://doi.org/10.3390/ijerph16030486

Pranata, R. H. (2017). Interaksi Sosial Suku Sunda Dengan Suku Jawa (Kajian Akulturasi dan Akomodasi di Desa Buko Poso, Kabupaten Mesuji. Swarnadwipa, 4, 9-15.

Procentese, F., Gatti, F., \& Di Napoli, I. (2019). Families and social media use: The role of parents' perceptions about social media impact on family systems in the relationship between family collective efficacy and open communication. International Journal of Environmental Research and Public Health, 16(24), 1-11. https://doi.org/10.3390/ijerph16245006

Rahayu, N. I., Suherman, A., \& Jabar, B. A. (2018). Hybridising Teaching Personal Social Responsibility (TPSR) and Problem Based Learning (PBL) in Physical Education. Jurnal Pendidikan Jasmani dan Olahraga, 3(2), 101-111. https://doi.org/10.17509/jpjo.v3i2.12395

Ratimiasih, Y. (2018). Analisis Interaksi Sosial Atlet Bola Voli Klub Ananta Kabupaten Semarang. Jendela Olahraga, 3(1), 79-85. https://doi.org/10.26877/jo.v3i1.2028

Rumahpasal, O., Kristinawati, W., \& Setiawan, A. (2020). Athletes' sports orientation viewed from parental social support and gender. Journal Sport Area, 5(2), 177-185. https://doi.org/10.25299/sportarea..vol().4775

Syaputra, H. (2020). Manusia dalam pandangan filsafat. Al-Hikmah: Jurnal Theosofi dan Peradaban Islam, 2(1), 13-28. http://dx.doi.org/10.51900/alhikmah.v2i1.7601

Setiyawan, S. (2017). Kepribadian Atlet dan Non Atlet. Jendela Olahraga, 2(1). https://doi.org/10.26877/jo.v2i1.1289 
Sinulingga, A., Simatupang, N., \& Mentari, S. (2020). Dampak agen sosial terhadap prestasi atlet pusat pendidikan dan latihan pelajar. Jurnal SPORTIF: Jurnal Penelitian Pembelajaran, 6(3), 794-806. https://doi.org/10.29407/js_unpgri.v6i3.15277

Sitepu, I. D. (2017). Pembentukan Karakter Melalui Partisipasi Dalam Olahraga. Jurnal Pedagogik Olahraga, 3(2), 99-112. https://doi.org/10.22245/jpor.v3i2.8209

Stefanski, A., Valli, L., \& Jacobson, R. (2016). Beyond Involvement and Engagement: The Role of the Family in School-Community Partnerships. School Community Journal, 26(2), 135-160.

Viandari, K. D., \& Susilawati, K. P. A. (2019). Peran pola asuh orang tua dan penggunaan gadget terhadap interaksi sosial anak prasekolah. Jurnal Psikologi Udayana, 6(1), 76. https://doi.org/10.24843/jpu.2019.v06.i01.p08

Burns, W. B. (2018). The Role of Social Media in Intercollegiate Athletics : A Synthesis of the Research Literature. Department of Kinesiology, Sport Studies, and Physical Education.

Xin, T. Y., \& Fitriana, M. (2020). The Athlete Performance Management: An Impact of Self-Integrity, Family Supports and Social Media. Journal of Education and Social Sciences, 12(2), 54-63.

Yunistiati, F., M. As'ad, D., \& Farid, M. (2014). Keharmonisan Keluarga, Konsep Diri. Persona, Jurnal Psikologi Indonesia, 3(1), 71-82. https://doi.org/10.30996/persona.v3i01.371 